\title{
Chinese walls: Australian multiculturalism and the necessity for human rights
}

Andrew Jakubowicz

Cosmopolitan Civil Societies Research Centre, University of Technology Sydney.

a.jakubowicz@uts.edu.au

\begin{abstract}
Australian multiculturalism is undergoing major challenges, reformulations and re-invigoration. In part this is due to the rapidly increasing presence of Chinese communities. In the past 'The Chinese' were both a major trigger for the creation of and later protagonists for the abolition of White Australia. The complex and multiple layers of engagement of the Chinese in the Australian political system range from inter-governmental relations, through national political and policy issues, to local politics. Their involvement in a wide range of political parties and the interweaving of international and national politics, and economic and policy decisions, indicates political and policy changes that may transcend the problematic of a multiculturalism constituted before the terror attacks of 2001 and before the rise of China as an international economic and political force in the wake of the 2007-8 Global Financial Crisis (GFC). Moreover the effective integration of the Chinese into Australian society may depend on how well the human rights dimension of multicultural policy is applied and conveyed to and through the Chinese population.
\end{abstract}

\section{Introduction: Multiculturalism in modern Australia}

The Australian government's apparent recognition in early 2011 that the country's contemporary challenges required a re-invigoration of a multicultural policy that elsewhere was suffering abandonment and condemnation, significantly reframed the ethnic political landscape. Multiculturalism encompasses the concept of identification, referring to the sense that "belonging to one's country is necessary to make a success of a multicultural society" (Modood 2007:150). It requires "a citizenship and the right to make a claim on the national identity in which negative difference is challenged and supplanted by positive difference” (Modood 2007:153).

The policy statement by the Government was supported by the conservative Opposition, supposedly inheritors of the low profile small-m multiculturalism of the Howard years. By the NSW State election of March 2011, both the Liberal leader Barry O’Farrell and the ALP Premier Kristina Kenneally were proudly heralding their support for multiculturalism. Ultimately the Liberal Party won that state election, with huge swings towards it in the heavily ethnic areas of western Sydney; "several major communities, especially the Chinese, moved en bloc from Labor to Liberal in key seats. This cost Labor several seats, particularly Strathfield(20\% swing) and 
Rockdale (13\% swing), and took Labor to the brink of defeat in Kogarah (15\% swing)” (West 2011).

If multiculturalism as a policy discourse in national government can oscillate between denial and celebration so remarkably in fairly short periods, what are the social factors that contribute to this dynamism? What does the politics of multiculturalism reveal about the role of government and civil society in managing the contradictions of a poly-ethnic polity? These questions require an exploration of the changing position, role and influence of Chinese communities as participants in the contemporary Australian political scene. The Chinese provide an important case study of a network of communities with a common 'image' in wider Australian society (Tan 2006), who are however extraordinarily diverse, complex and differentiated by location, history, culture, language, politics, origin and class. The numbers of Chinese are rapidly rising; at the same time, they are one of the few communities which is both large in resident numbers, and part of a wider global diaspora that is economically of great importance to Australia.

Unlike other immigrant communities who arrived in large numbers after World War 2, such as the Italians and Greeks, the Chinese arrivals of the past two generations and their predecessors from the days before White Australia (1901-1973) are important within Australia, yet are also linked to regional economies that are crucial to Australia's economic survival (which many other immigrant groups are not). Only the British have demonstrated a comparable pattern of major population presence and global trading and political importance. In addition, the concentration of the Chinese in particular urban localities and their economic strength gives them an increasing degree of political potential similar to longer-established European-origin communities.

The Vietnamese and other Indo-Chinese intake of the late 1970s finally ended the White Australia mind-set of government. Australia adopted multiculturalism through the Parliamentary tabling of the Galbally Report in 1978 in ten languages (Galbally 1978). Even so, while White Australia had passed from government policy settings, it had not disappeared from Australian society. Prof Jerzy Zubrzycki, a key adviser to the Fraser government, warned as early as 1977 (as the Galbally Report was being finalised) that there was widespread opposition still to nonWhite immigration (Zubrzycki 1977;1995).

Meanwhile Australia's trade with China was growing rapidly, and the first immigration from Hong Kong, Taiwan and the Chinese diasporic communities of Singapore, Malaysia, Indonesia and Indo-china was also expanding. Through the 1980s Asian immigration increased and moments of major social reaction emerged. In 1984/85 historian Geoffrey Blainey identified dangers in Asian immigration and multiculturalism (Blainey 1984). Also in 1984 Britain signed the agreement to hand back Hong Kong to China in 1997, prompting a new demand for immigration opportunities. 
The June 41989 Tiananmen democracy confrontation changed the underpinning for Australia's policy on Chinese immigration once more. The Hawke government decided that some 40,000 students from China studying in Australia would be able to stay if they wished. The following year the Human Rights and Equal Opportunity Commission reported on the upsurge in racist violence in Australia, consequent on the debate that Blainey's comments had triggered half a decade before (HREOC 1991).

The 1996 federal election won by the Coalition under John Howard, an opponent of multiculturalism, also marked the appearance on the national scene of newly-elected Queensland independent and former Liberal MP Pauline Hanson. She advocated a return to a unitary premulticultural Australia (Jakubowicz 1997/2010). While Hanson's success and the consequent rise of the One Nation Party she later established did much to destroy the bi-partisan support for multiculturalism that had dominated the period from 1976 to 1985, in retrospect the forces that Zubrzycki had warned of at the very advent of the policy were never far from the surface in the public debate.

Hanson's election focused public attention on her primary target, 'Asians' whom she believed had failed to assimilate into Australian society. While the public debate generated by Blainey's comments had primarily concerned Indo-Chinese refugees and immigrants, it was in fact the surging numbers of ethnic Chinese from diverse origins (including Indo-China) who were transforming Australia's ethnoscape (Appadurai 1996: 27, 45): it was to be the unique combination of their numbers, diversity, education levels, economic capacity, diasporic linkages and international political leverage that would make the Chinese such an important dimension of the next fifteen years of debate about multiculturalism. They were to be the most high-profile community to take a stand against the diminution of multiculturalism, key participants in the return of the ALP to federal power in 2007, a major influence on the rebirth of multiculturalism, and then significant contributors to the transformation in the Australian political landscape towards the conservative parties that occurred from 2010 onwards.

\section{Who are Australia's 'Chinese’?}

The Chinese reside in Australia as citizens, settlers, transient workers, students, business people, diplomats and other government officials, refugees and short term residents. The diversity within the category reflects the complexity of the Chinese diaspora and the political argument about what it means to be Chinese. The Peoples' Republic of China (PRC) is a vast country itself encompassing enormous diversity while the Chinese extend far beyond the PRC. Virtual Huaren (ethnic Chinese - 'ren' people, 'Hua' Chinese) networks build these diasporic interconnections. Yet they are only one part of the story. 
The diversity of the Chinese in Australia reflects their complex histories. Even though Chinese had arrived before the gold rushes of the nineteenth century and at times and in places were the majority non-Indigenous population (e.g. on the northern Queensland gold fields at Palmer River in the 1880s), the Commonwealth of Australia found common purpose amongst its former colonies in uniting against further Chinese immigration. This was realised through the enactment of the 1901 Immigration Restriction Act, the basis of what became known as 'White Australia Policy'. From 1901 on the Chinese population began to decline, even though strong pockets survived in the main cities and some rural areas throughout the first half of the twentieth century. While some wartime South East Asian diasporic Chinese refugees found safety in Australia after the Japanese expansion south from 1941, they were expelled from Australia after 1945. Ethnic Chinese nevertheless continued to come and go in small numbers despite bans on permanent residence. However as indicated above, with the end of White Australia in the 1970s, Chinese immigration grew rapidly, fuelled both by changing circumstances in the region, and by acceptance in Australia.

By the end of the first decade of the 21st century, this diversity in the Chinese presence was reflected in the many different 'kinds of Chinese' identifiable in the wider community. The descendants of the earliest settlers, long isolated from China though in contact with other regional diasporic centres, had become part of the wider Australian society, often with no memory of Chinese language. They had been enhanced by the Colombo Plan generation of the 1960s, mainly English-speaking tertiary educated Chinese diaspora from Singapore, Malaysia, etc. Some were Chinese Malays with radical political views who came to Australia in the postMalay insurgency period, especially those who feared the rise of Malay nationalism.

With the end of White Australia Policy in the early 1970s, Australia became more open to the wider Chinese diaspora in the region. Some came as refugees at the end of the Indo-China war in 1975, from south Vietnam, Cambodia and Laos. Soon changes in China itself with the end of the Cultural Revolution and the easing of international movement restrictions permitted PRC citizens to leave, often gaining entry to Australia as skilled immigrants, or for a shorter term as students. In addition to the 40,000 Chinese students allowed to stay in Australia following the Tiananmen events of June 4 1989, over the next decade refugee applications from Chinese citizens for other reasons also increased.

Meanwhile P R China's claims to be the suzerain in some sense of all ethnic Chinese, whether resident on the mainland, in Taiwan or elsewhere, had additional effects in Australia. While the 1984 signal of the hand-over of Hong Kong began the process of Hong Kong residents assessing their future options, the hand-over itself in 1997 created another stream of immigrants to Australia, both prior to and after the event. As key areas of Australia's capital cities became more 'Asianised' in design and population, so they increased their attraction for other Chinese groups. Brisbane for instance became a magnet for people from Taiwan, making the Taiwanese a 
more significant part of the local Chinese population than in any other city (Kwok 2011): Australia-wide the Taiwan-born population grew by 17\% in just the year 2008-2009 (ABS 2010).

China's own regional policies played a role in the immigration of its non-Han citizens. Foremost among these were refugees from Tibet, especially as government pressure on the country increased with the rising number of Han Chinese relocating there. Similarly, Uighurs from Xinjiang, mainly Muslim Mongol peoples, while claimed as Chinese, brought with them a long history of resisting incorporation into Beijing's zone of control.

Another rapidly growing group encompasses those who now figure in the Australian Bureau of Statistics Nett Overseas Migration calculations (NOM), even though they hold visas only for short-term residence. These groups now constitute a major component of the Chinese population, with three significant elements: the so-called 457 skilled guest-workers (employer-sponsored and with limited freedom of action outside the visa conditions), international students, and business visa holders[i].

Other categories include people who arrive on a short-term visa and then claim refugee status (RRT 2008), often seeking recognition for claims of suffering persecution as members of Falung Gong or as Christians. At the opposite end of the social scale are short term business managers, skilled workers, professionals and officials associated with large Chinese development projects, especially in the minerals extraction industry. China and Taiwan also have diplomatic, security and news agency staff, some of whom monitor all the other groups. There may indeed be other categories, and of course there are significant provincial/regional variations in migration histories, languages spoken, skill levels and education (Collins and Reid 1995).

\section{Why contemporary Chinese settlement in Australia sets up new issues}

The engagement of the Chinese diaspora with Australian political, economic and cultural life has thrown into sharp relief the insufficiency of traditional multiculturalism as providing an intellectual structure for analysis and a policy framework for response. This is not to discard multiculturalism, but to note that it can engage with only certain parts of the Chinese experience of and presence in Australia, and wider Australian engagement with the Chinese and the Chinese nations (PRC and Taiwan). In turning to a closer reading of the diversity of the Chinese engagement with Australia, and Australia's engagement with the Chinese, the changing political environment at a global level throws some light on the issues raised.

One of the more important dimensions can be found in the 'ideology' developed by the PRC to tell the 'story of the nation'. Feng (2011) notes a shift in official P R Chinese ideology after Tiananmen from a celebration of socialist achievement to an advancement of greater Han 
nationalism. During this period the tenor of discussion in Australia has addressed the specific qualities of 'Chineseness', rather than canvassing the older fear of Chinese Communism that dominated the 1950 to 1980 period. However the authoritarian/totalitarian nature of the PRC state has remained one component of the Australian conversation about China. The other significant component lies in the economic super-status of China and its role in Australia's economic welfare, where expanding Chinese productive capacity has been the major factor in the so-called 'mining boom' in Australia, before the Global Financial Crisis, during the recession, and since the recovery began to be apparent in 2010.

In 1976 at the first Census after the official end of White Australia, there were about 20,000 people who had been born in China (though many others would see themselves as Chinese). In 2001, the Census recorded some 143,000 born in China, which rose by 45\% to 207,000 in 2006. By 2009, the China-born population had reached 351,000 ( an increase of some 144,000 or $70 \%$, of which about 90,000 is from permanent arrivals), with Hong Kong-born at 89,000 and Taiwan-born at 37,000 (ABS 2010). In 2008/9 the collectivity of identifiable Chinese (PR China, HK, Macau, Taiwan) made up the largest of the non-British permanent settler immigrant intakes, at over 30,000 [vc6] (ABS, 2010).

By the 2006 Census, some 700,000 Australians would trace a Chinese ancestor; people born in the Peoples’ Republic of China made up the third largest overseas-born group after the United Kingdom and New Zealand. Chinese language speakers formed the second-largest language group after English, and Chinese formed the seventh largest ancestry group despite a fairly short recent immigration history. Unlike most other birthplace groups, the Chinese-born are increasingly spatially concentrated in Australia, lending weight to the sense of their locational influence and potential power (Coughlan 2008). 'Chinese' can be understood in a number of ways- as declared ancestry, as country of birth, or as language chosen to be spoken at home. In the 20 years from 1986 to 2006, the PRC-born population rose, albeit from a low base, by over $600 \%$, people identifying Chinese ancestry by over 330\%, and Chinese language speakers by over $400 \%$.

By 2010 Sydney’s Burwood, the most densely Chinese-populated local government area in Australia (Coughlan 2008), had two of its seven councillors of Chinese background, one from the Australian Labor Party and the other from the Liberal Party. Of the ten most Chinese populous localities the first five were all in Sydney, with three others in Brisbane. For some localities, the growth while dramatic, has been regular. Burwood's Chinese rose from about 2000 in 1986, to 5500 in 1996 (about 75\%), then again to about 7500 in 2001, and to over 11,000 in 2006. Ashfield, which took many of the Tiananmen students, rose from just over 1000 in 1986, to about 8500 in 1996 (850\%), falling back slightly as this group diffused locally to adjacent LGAs. The Brisbane suburbs of Sunnybank and Robertson were much slower to 'take off', less affected by the Tiananmen period, with their most dramatic growth in the 2001/2006 period ( 
Sunnybank rising 3000 to 8000 , or $170 \%$, and Robertson 3000 to about 7500 , or $150 \%$ ) (figures recalculated from Coughlan 2008).

The Chinese population is well educated (including the international student body) and concentrated in key areas of the 'global economy' such as IT and commerce. In general the Chinese represent the first large scale immigrant community which is already well-educated on arrival, and concentrated in strategic economic sectors. The class and education pattern of immigration from Europe in the 1950s and 1960s tended towards the low-skilled sector, while that from Indo-China in the 1970s and 1980s tended also to show the effects of war on broken educational opportunities.

Table 1: Level of education and sector of employment by country of birth

\begin{tabular}{|l|l|l|}
\hline Level of education & PRC-born \% & All Australians \% \\
\hline Post grad degree & 15.7 & 3.9 \\
\hline Grad Dip/cert & 1.6 & 2.2 \\
\hline Bachelor degree & 24.6 & 16.2 \\
\hline Advanced Diploma etc & 12.4 & 9.5 \\
\hline Certificate & 6.2 & 21.3 \\
\hline No qualification & 37.0 & 45.2 \\
\hline Field & & \\
\hline Info tech & 10.7 & 3.5 \\
\hline Engineering & 17.7 & 20.3 \\
\hline Management commerce & 32.1 & 20.8 \\
\hline Other & 39.5 & 55.4 \\
\hline
\end{tabular}

(ABS, 2006 Census)

The Chinese immigrant population, arriving from a country with which Australia has rapidly expanding economic ties, enters a situation significantly different from that faced by earlier immigrant groups. By comparison, while immigration from Greece, Italy, Yugoslavia and Turkey grew rapidly during the 1950s,1960s and 1970s, and from Vietnam in the 1980s, Australia did not have a major economic stake in trade with their countries of origin. In contrast, China's economic links with Australia continue to deepen. 
In the decade 1999 to 2009, during which Chinese immigration grew substantially, Australia's trade with P R China grew from about \$18 billion (imports and exports) to about $\$ 85$ billion, with a five year export trend growth of $27 \%$ p.a.. In the three years 2007-2009,Chinese international students in Australia grew in export dollar value from \$2.7 billion (contributing about about $12 \%$ of total Australian exports to China including minerals and agricultural products) to $\$ 4.1$ billion (contributing about 10\%), giving a five year trend line of nearly $19 \%$ annual growth, with a total figure of 154,000 students in 2009 (DFAT 2010).

The Chinese community thus represents an emerging and unique constellation of factors that multiculturalism was never designed to accommodate or manage. Australia faces a growing part of the population whose earlier socialisation has been increasingly influenced by Han nationalism (Ho and Chio 2010, Feng 2011), yet who demonstrate early settlement period focus on employment, housing and education, rather than politics. Furthermore, in a climate of apparently vacillating Australian government support for multicultural social justice, equity and human rights, and where Australia's economic well-being is believed to depend on good relations with the PRC (White 2010), the public policy challenges of ensuring equitable access to scarce public resources, including political representation, continue.

\section{The Chinese in Australian public awareness}

The March 2010 Lowy Institute survey of Australians’ attitudes to international affairs and China argued “that Australians are increasingly conscious of China's rise and are starting to grapple with its implications. Indeed China looms so large that Australians have developed a somewhat exaggerated view of its global weight” (Shearer 2010). China's economic role through the purchase of raw materials had seen Australia safely through the GFC (Laurenceson, 2008). 73\% of Australians (up 10\% from 2008) thought China's growth had been good for Australia, although about the same proportion thought that China's aim was to dominate Asia (up 9\% since 2008). While happy to sell commodities to China, Australians were more reluctant to sell freehold to China - 57\% thought the government allowed too much Chinese investment (up 7\%). In addition 46\% thought China would become a military threat within 20 years (up 5\%). Meanwhile 2/3 believed Australia was soft on China's transgression of human rights. Clive Palmer a Queensland billionaire mining magnate summarised the complexity when in September 2009 he condemned as racist the government's insistence that Chinese investments receive Treasury approval, claiming in relation to $\$ 1.8$ trillion of Chinese reserve capital "We've got the opportunity to grab that if our politicians could only be fair and treat the Chinese people and Chinese government with the dignity they deserve" (Marriner 2009).

Apart from the Foreign Investment Review Board criteria for differentiating Chinese from other sources of capital inflow, the government amended the Commonwealth Electoral Act in 2009 to 
outlaw foreign property donations to Australian political parties or involvement in political campaigns. Figures released by the Australian Electoral Commission in early 2009 (http://periodicdisclosures.aec.gov.au/) covering the 2007 Federal election identified a number of Chinese business people, especially linked to gambling and property development, as having made significant donations to both the major political parties. Some donations had been returned after failing ethical screenings (see Jakubowicz 2011).

The picture of Australian national apprehension of China reflects the many different interests that Australians have - ranging from primary producers and resource companies, through manufacturing industry [au7] and infrastructure providers, to finance and education sectors. The most significant factor relates to the scale and interdependence of economic relations, where the Chinese economy is felt to now play a determining role in the viability of the Australian economy. For the first time since early British empire days a foreign power now has both influence if not control over significant parts of the Australian economy and a large resident population. However unlike the British example, China has a central state strategy that integrates the role of diverse Chinese companies in Australia into a broader global strategy focused on resource security (as it does elsewhere in the Pacific and in Africa and South America). The specific form of the Chinese state with a central directing political elite, its concern for resource and energy security, and its intensifying emphasis on the ethno-nationalist underpinning of the Chinese cultural diaspora, moves us beyond the older form of interest-group pluralist politics that typified multiculturalism in its first thirty years (Levey 2008).

\section{Multicultural politics and Chinese diversity}

A high proportion of Australia’s 'Chinese' live in the Sydney Statistical Division (SD). In 2006 about 53\% of all Australia’s China-born population lived in the Sydney SD, comprising some $71 \%$ of the total 'Chinese' population in the city (including PRC, HK, Taiwan); some of the PRC-born may moreover have been long-term residents of Hong Kong or Taiwan prior to immigration.

About 230,000 people claim to speak at least one of the named Chinese languages (Cantonese, Mandarin, Other), far higher than the 150,000 who were born in one of the Chinas. Of these about 125,000 speak Cantonese, and 97,000 Mandarin, with 12,000 speaking Other languages (Teochew, Hokkien and Hakka). About 290,000 claim Chinese ancestry, of whom 270,000 had both parents born overseas, with only 6000 having both born in Australia. Mandarin speakers (from the mainland and Taiwan) have a lower likelihood of being Australian citizens than Cantonese speakers (61\% vs. 86\%), reflecting the historical political pressure for Australian citizenship among Hong Kong and Macau origin settlers, perhaps the reluctance of many PRC citizens to give up their PRC citizenship, and also recency of arrival. However to confuse matters slightly, over a thousand Sydney residents born in China claimed both Russian Orthodox 
religious affiliation and Russian ancestry, while over 400 claimed Russian Orthodoxy and Chinese ancestry (calculated by the author from CDATA through ABS Census 2006).

This diversity has been well documented (e.g. Ang 2000), as its effects contribute to an apparent impossibility of a unified or cohesive Chinese political presence in Australia (though clearly not solely a characteristic of Chinese groups but more widely spread among ethnic communities). North American studies have pointed to the relatively low level of formal political representations of Chinese communities in the USA and Canada, relative to their size (Freedman 2000; Fernando 2006). Three reasons are suggested for this situation among those who accept such claims: community fragmentation absorbs energy in intra-communal struggles for influence; the focus in the first generation on economic establishment and success absorbs most of the creative energy available to recent settlers - they would be more interested in Chinese schools than in Chinese politicians; and power is exerted through influence networks (mobilizing guanxi or influence through personal and family connections) (Hutchings \& Murray 2002) rather than through access to authoritative institutional roles in the host society (Chin 1997; Kwok 2008, 2011; Gao 2006, 2009).

'Chinese' is therefore not such a bridging label as might commonly be thought. But is this any different to what might be said of earlier immigrant communities, and their marginalisation through the first generation of settlement (Zappala 1998)? Given the diversity identified above, it might be argued that the Chinese barely share enough of a common interest to be thought of as a cohesive 'interest group'. Multicultural political analysis tends to examine ethnic groups as a sub-set of interest group politics, and thereby constructs a view of Australian society that frames ethnic communities as interest groups - with specific, usually first generation, concerns (Jupp 1984; Jupp et al. 1989; Kymlicka 2007; Lopez 2000; Modood 2007). The standard ideological rhetoric of multiculturalism's advocates usually seeks to mobilise wider social support through foregrounding concepts such as productive diversity, and arguing for its role in enhancing cosmopolitan capabilities in society, including bi-lingualism and intercultural communication competence (AMAC 2010). In this view, a sustainable multicultural polity could be said to depend on well-organised ethnically-focused organisations able both to articulate the particular interests of their groups, and engage in coalitions with similar groups to deliver broader policy outcomes that provide individual benefits to the groups, and to their constituencies (Levey 2008). Some of these organisations are purely local, some are international but locally-focused (e.g. clan groups), while some are trans-national (China/Australia) and others international (e.g. diasporic multi-nation associations)(Lever-Tracy et al. 1996; Suryadinata 2004).

While 'Chinese' communities harbour a multiplicity of such groups and institutions, with interlinkages to commercial or quasi-commercial enterprises, there are now emerging a number of groups that specifically foreground the issues raised by participation in this multicultural polity, 
given the history of White Australia. Despite their diversity, they may indeed share one common challenge, that of Australian racism and the racialisation of Australian public life and discourse.

The racism that has been a defining characteristic of Australian society in the past has not simply dissipated. Dunn (2003) has found that Australians are less (but even so still) prejudiced against 'Asians' than they are against Muslims and Indigenous people; even so Booth et al. (2009) identified the Chinese as the group most likely to suffer discrimination in employment on the basis merely of their names. Critics (Dunn et al. 2011) have argued that one of the major problems with Australian multiculturalism lies in systematic failure by government to engage with residual racism; indeed denial of racism has been a more likely response by government when confronted with inter-communal violence, than any sustained strategy of intervention (see Dunn and Nelson, this issue). Even the Government's own Australian Human Rights Commission had criticised government inaction on racism in its submission to the United Nations (AHRC 2010). It was not until February 2011 in the policy announcement referred to above, that the Government announced the first full-time Race Discrimination Commissioner for over a decade, and a national anti-racism strategy.

Australian Chinese have been involved in anti-racism politics from the first period they experienced its full force, soon after their arrival on the Victorian goldfields. They organised joint petitions with European miners and business people seeking equality of treatment, by colonial governments. In the lead up to Federation they organised and lobbied ultimately unsuccessfully both for recognition as equal members of Australian society, and for government action to reduce discrimination and prejudice (Fitzgerald 2007b). Major struggles erupted during the post-war (1946) attempts to expel Chinese refugees, while Chinese Australians were part of the 1960s struggle to end White Australia (Fitzgerald 2009).

By the time of the Blainey controversy Australia's 'new Chinese' were again actively involved in anti-racist politics. The Sydney-based Chinese Australian Forum was founded in 1986 as a 'unity' movement to resist the re-racialisation of political discourse; similar groups emerged in Melbourne and Brisbane. They organised street rallies, ran meetings, prepared petitions, and generally developed a close set of links with progressive non-Chinese anti-racism activists, even though their own electoral base was somewhat limited. Moreover a decade later with the rise of Hanson their own base had expanded and their capacity and willingness to collaborate on antiracism issues had become more sophisticated.

Chinese Australians have gained representation (usually at state level) in periods when racepolitics have been salient for the wider society, especially during the Hanson/One Nation ascendancy. During that time in NSW the anti-Hanson Unity Party elected Dr Peter Wong (formerly a Liberal member) to the Upper House, while former Liberal Party Upper House MP Helen Sham Ho left the party and sat as an independent. In Victoria Chén Zhībīn was elected to 
the Senate for the Liberal Party (1999-2005) winning pre-selection against an incumbent, then losing it next time around. That is, the Chinese were most likely to be successful when the wider social sentiment was more responsive to anti-racist arguments (paradoxically perhaps if Hanson's ascendancy is the touchstone) and to do so within the conservative side of politics. A September 2010 Sydney Chinese in politics symposium (http://vimeo.com/17991025 at $18 \mathrm{~min}$ $30 \mathrm{sec}$ ) heard from Dr Wong, who complained about the disappearance of Chinese politicians from Australian public life over recent years. In response a group of younger politicians in local government argued that they were now building political careers that were inter-ethnic, suggesting that the community's perspective had changed somewhat, to accommodate to a visibly and culturally-diverse Australia.

The Chinese community's strong support for the successful ALP candidate Maxine McKew in the seat of Bennelong against then Prime Minister John Howard in 2007 reflected the view in the Chinese (and other Asian) communities that the Liberal Party under John Howard had adopted views that they experienced as racist, and that Howard symbolically represented the last embers of White Australia (Saville 2007). However Chinese community leaders expressed disappointment with the replacement of the Mandarin-speaking Kevin Rudd as PM, the failure of the ALP government to adopt a Bill of Rights, the failure in 2010 to advance a policy on multiculturalism, or to signal a public commitment against racism. Asian communities were to reduce if not withdraw their support for McKew at the 2010 election, and she lost the seat. By 2011 they were part of a general turn towards the LNP at the NSW state election, which produced the huge swing away from the ALP described above.

\section{Overcoming the insufficiency: using the Chinese question to modernise Australia's multiculturalism}

The 'Chinese' question raises for Australian political life the first major case of a postmulticultural politics, where people who have settled in Australia also remain connected to an immigration source country with large scale economic ties to Australia. If so, the problem should register in public policy. A joint Parliamentary Inquiry into Multiculturalism by the Migration Committee in mid-2011 received over 350 submissions exploring the policy and its future prospects (http://aph.gov.au/house/committee/mig/multiculturalism/subs.htm). For the first time the Australian government's exploration of multicultural policy was framed by issues associated with globalisation, with particular emphasis placed on source countries "in the region”, code primarily for China, and the role of diaspora populations in sustaining economic, cultural and political links.

How these links might work, and what they might mean for domestic multicultural policy remain to be seen. However, the implications of patterns of participation that are said to be common among Chinese diasporas in the West, suggest a far greater emphasis will be needed on core 
practices to minimise racism. Freedman (2000) in her examination of Chinese in the political life of the USA found that the two key assumptions widely held in the scholarly literature and 'in popular opinion', that the Chinese are pawns of their homeland governments, and they are politically passive preferring to concentrate on economic advancement, were not upheld by recent research. The useful distinction is made between political influence and political participation, where influence reflects economic power, while participation depends on the political system's openness to new entrants (2000:183). Fernando (2007) uses a 'critical multiculturalism' paradigm to compare Toronto and Los Angeles. The same contradiction exists, she finds, between economic success and apparent political exclusion. The problem she argues lies in the tension between a racialised state structure and a public ideology of equality, producing a 'democratic deficit'. Multiculturalism as an ideology may disguise the realities of unequal access to power, where active blocking by existing power elites denies access to the formal political system.

As globalisation intrudes increasingly into the domestic political world of Australia the democratic deficit ascribed by Fernando (2007) to ostensibly open political systems that remain enveloped by racialised hierarchies of access and power, emerges as an increasing challenge. Political systems that fail to recognise inequalities and barriers to mobility enshrined by cultural power can be faced with significant shifts in allegiance, and internal dislocation (Drapac 2009). With the maturation of new generations of younger Chinese Australians, their social and economic mobility now points to their likely greater political engagement. Australian multiculturalism needs to demonstrate its human rights priorities, so that those who are potentially caught in the strengthening diasporic ties with the Chinese homelands can mobilise Australia's vision of an egalitarian, non-racist and rights-based political discourse both to find their place within Australian society, and undertake a robust dialogue with their putative country of origin.

The ongoing debates about Australia's multiculturalism draw from the broad range of society both vigorous support for and angry condemnation of the policy (Galligan and Roberts 2008). Yet for the sense of shared ownership towards which Tariq Modood alludes to become an ongoing reality, an emergent Australian multicultural nationalism has to include rather than marginalize its 'Chinese' citizens. If tensions exist they can best be moderated by asserting an inclusive program that validates difference while stressing common values associated with universal human rights.

The withering of multicultural policy that Australia has witnessed for more than fifteen years, its low levels of resource and its lackadaisical implementation indicates that a new formulation is required. A renewed policy would allow Australia to articulate its future in the region and promote social integration of a diverse population. However, more than rhetoric is needed, given the deep structural discrimination revealed by the analysis of the Chinese experience in 
multicultural Australia. A strong and renewed multicultural policy that would ensure effective recognition of difference while reasserting the importance of reciprocal respect between cultural communities would do much to overcome the democratic deficit that otherwise could erode wider social inclusion.

\section{References}

Ang, I., 2000. Transforming Chinese identities in Australia; between assimilation, multiculturalism and diaspora, in See, T.A. ed., Intercultural relations, Cultural Transformation and Identity - the Ethnic Chinese, Selected papers presented at the 1998 ISSCO Conference, Manila: Kaisa Para Sa Kaunlaran.

Appadurai, A., 1996. Disjuncture and difference in the global cultural economy. in Modernity at Large. Cultural Dimensions of Globalization, Minneapolis: University of Minnesota Press, 2747.

Australian Bureau of Statistics (ABS)., 2010. Migration Australia, 2008-09. 3412.0, Canberra. Australian Human Rights Commission (AHRC)., 2010. Submission to the ICERD Committee on Information concerning Australia and the International Convention on the Elimination of All Forms of Racial Discrimination (ICERD), July 8, at http://www.humanrights.gov.au/legal/submissions/united nations/ICERD2010.html. Australian Multicultural Advisory Council (AMAC). 2010. The People of Australia, Canberra, April.

Blainey, G., 1984. All for Australia. North Ryde, N.S.W: Methuen Haynes,. Booth, A., Leigh, A., and Varganova, E. , 2009. Does Racial and Ethnic Discrimination Vary across Minority Groups? Evidence from a Field Experiment. IZA Discussion Paper No. 4947 May. http://www.melbourneinstitute.com/downloads/hilda/Bibliography/wp/Booth_etal_Racial_Discri mination_IZA_dp4947.pdf

Bowen, C., 2011. Multiculturalism in the Australian Context. Speech to the Sydney Institute at http://www.katelundy.com.au/2011/02/17/minister-for-immigration-and-citizenship-chrisbowen-multiculturalism-in-the-australian-context/.

Chan, H., 2001. Becoming Chinese But Remaining Australasian: The Future of the Down Under Chinese Past. in Chan, H., Chiag, N., \& A. Curthoys, A., eds. The Overseas Chinese in Australasia: History, Settlement and Interactions. Taipei and Canberra: National Taiwan University and Australian National University, 1-15.

Chin, K.H., 1997. Intra-ethnic conflict among the Chinese in Sydney, Ph.D thesis, Australian National University.

Collins, J., and Reid, C., 1995. Chinese in Australia 1945-1994 : changing patterns of migration, racialisation and opportunity. Sydney: School of Finance and Economics, University of Technology, Sydney.. 
Coughlan, J. , 2008. The changing spatial distribution and concentration of Australia's Chinese and Vietnamese communities: An analysis of 1986-2006 Australian population census data. Journal of Population Research, 25 (2), 161-182.

Department of Foreign Affairs and Trade (DFAT)., 2010. Australia’s trade with East Asia 2009. Market Information and Research Section, August, at http:/www.dfat.gov.au/publications/statspubs/Australia-trade-with-East-Asia-2009.pdf

Drapac, V., 2009. Active citizenship in multicultural Australia. Humanities Research, XV (1) 5973.

Dunn, K., 2003. Racism in Australia: findings of a survey on racist attitudes and experiences of racism. National Europe Centre Paper No. 77, Sydney: The University of New South Wales. Feng, C., 2011. The changing political identity of the 'Overseas Chinese' in Australian Politics. Cosmopolitan Civil Societies Journal, 3 (1), 121-138.

Federation of Ethnic Communities Councils of Australia (FECCA). 2011. Here to Stay: Australia's Multicultural Reality, athttp://aph.gov.au/house/committee/mig/multiculturalism/subs/sub176.pdf Fernando, S., 2006. Race and the City: Chinese Canadian and Chinese American Political Mobilization. Vancouver: University of British Columbia Press.

Fitzgerald, J., 2007. Big White Lie: Chinese Australians in White Australia. Kensington: UNSW Press.

Fitzgerald, J., 2009. John Fitzgerald on how Chinese endorsed Federation. Making Multicultural Australia at http://www.multiculturalaustralia.edu.au/library/media/Video/id/1119.JohnFitzgerald-on-how-Chinese-endorsed-Federation Fraser, M. and Simonds, M., 2011. Malcolm Fraser: The Political Memoirs. Melbourne: The Miegunyah Press.

Freedman, A., 2000. Political Participation and Ethnic Minorities: Chinese Overseas in Malaysia, Indonesia, and the United States. London: Routledge.

Galbally, F., (chair) 1978. Migrant Services and Programs, Review of Post Arrival Programs and Services for Migrants, Canberra: Australian Government Publishing Service.

Galligan, B. \& Roberts, W., 2008. Multiculturalism, national identity and pluralist democracy: the Australian variant', in Levey, G. ed., Political Theory and Australian Multiculturalism. New York and Oxford: Berghahn Books, 209-224.

Gao, J., 2006. Radio-activated business and power : a case study of 3CW Melbourne Chinese radio, in Sun, W., ed., Media and the Chinese diaspora : community, communications and commerce. London: Routledge, 150-177.

Gao, J., 2009. Lobbying to stay: The Chinese students' campaign to stay in Australia, International Migration. 47 (2), 127-154.

Human Rights and Equal Opportunity Commission (HREOC)., 1991. National Inquiry into Racist Violence. Canberra: AGPS. 
Hutchings, K. \& Murray, G., 2002. Working with Guanxi: An Assessment of the Implications of Globalisation on Business Networking in China, Creativity and Innovation Management. 11, 184-192.

Jakubowicz, A. 1997/2010. Is Australia a racist society? : reflections on globalisation, multiculturalism and Pauline Hanson. Jakarta: Australia Indonesia Institute, and at http://andrewjakubowicz.com/publications/is-australia-an-racist-society-reflections-onglobalisation-multiculturalism-and-pauline-hanson/

Jakubowicz, A., 2009. New Groups and Social Cohesion in Australia. in Higley, J., Nieuwenhuysen, J., with Neerup, S., eds. Nations of Immigrants: Australia and the USA Compared. London: Elgar.

Jakubowicz, A., 2011. Empires of the Sun: towards a post-multicultural Australian politics, Cosmopolitan Civil Societies Journal. 3 (1), 65-85.

Jupp, J., 1984. Ethnic politics in Australia. Sydney: Allen \& Unwin. Jupp, J., McRobbie, A., York, B., 1989. The political participation of ethnic minorities in Australia, , Canberra: AGPS for Centre for Immigration and Multicultural Studies, ANU. Kwok, J.T., 2008. Clientelism in the ethnopolis: ethnic contribution networks and political fundraising under late multiculturalism , Journal of Australian Studies, 32 (4), 467-479. Kwok, J.T., 2011. Chinese Australian Urban Politics in the Context of Globalisation, Cosmopolitan Civil Societies Journal, 3 (1), 86-102.

Kymlicka, W. 2007. Multicultural Odysseys: Navigating the New International Politics of Diversity. Oxford: Oxford University Press.

Laurenceson, J., 2008, Chinese Investment in Australia. Economic Papers 27 (1): 87-94 Lever-Tracy, C., Ip, D.F.-K. \& Tracy, N., 1996. The Chinese diaspora and mainland China : an emerging economic synergy, Houndmills, Basingstoke, Hampshire New York: St. Martins Press.

Levey, B., ed. 2008. Political Theory and Australian Multiculturalism. New York: Berghahn Books.

Lopez, M., 2000. The Origins of Multiculturalism in Australian Politics 1945-1975. Melbourne: Melbourne University Press.

Marriner, C., 2009. Mining mogul's racism claim. Brisbane Times, 30 September at http://www.brisbanetimes.com.au/business/mining-moguls-racism-claim-20090930gb9m.html

Modood, T., 2007. Multiculturalism: a civic idea. Cambridge: Polity. National Human Rights Consultation (NHRC). 2009. Report, Canberra.

Norington, B., 2010. Free world must hold firm on cultural identity in battle against terrorism, John Howard warns. The Australian, 29 September at http://www.theaustralian.com.au/national-affairs/dont-get-confused-about-multiculturalismjohn-howard-warns/story-fn59niix-1225931763267

Refugee Review Tribunal (RRT), 2007. Research Response Number: CHN32643 Country: China Date: 21 November. 
Refugee Review Tribunal (RRT), 2008. Research Response Number: CHN33487 Country: China Date: 7 July.

Saville, M., 2007. The Battle for Bennelong: The Adventures of Maxine McKew, aged 50something. Carlton: Melbourne University Press.

Shearer, A., 2010. Sweet and Sour: Australian Public Attitudes towards China. Sydney: Lowy Institute for International Policy.

Suryadinata, L., 2004. Ethnic relations and nation-building in Southeast Asia : the case of the ethnic Chinese. Singapore: Institute of Southeast Asian Studies.

Tan, C. 2006. 'The Tyranny of Appearance': Chinese Australian Identities and the Politics of Difference, Journal of Intercultural Studies, 21 (1) 65-82.

West, A., 2011. Ethnic voting trends prove powerful force. Sydney Morning Herald, 29 March, at http://www.smh.com.au/nsw/state-election-2011/ethnic-voting-trends-provepowerful-force-20110328-1cdis.html

White, H., 2009. Comment. The Monthly, at http://www.themonthly.com.au/nation-reviewedhugh-white-comment-rudd-s-china-policy-2186

White, H., 2010. Power Shift: Australia's Future Between Washington and Beijing. Quarterly Essay, 39, Melbourne: Black.

Wolin, R., 2011. Ghosts of a Tortured Past : Europe’s Right Turn. Dissent, 58 (1), Winter 5865.

Zappala , G., 1998. Clientelism, Political Culture and Ethnic Politics in Australia. Australian Journal of Political Science, 33 (3), 381-397.

Zubzrycki, J. (chair), 1977. Australia as a Multicultural Society. Canberra: Australian Ethnic Affairs Council.

Zubrzycki, J. 1995, The Evolution of the Policy of Multiculturalism in Australia 1968-95. Global Cultural Diversity Conference Proceedings, Sydney at http://www.immi.gov.au/media/publications/multicultural/confer/06/speech29a.htm.

[i] Changes to the calculation of the Nett Overseas Migration figures after 2006 'captured' many of the students and 457 holders who leave the country within twelve-months (for vacations in China), but return again over a number of years; NOM now includes data based on twelve months residence in sixteen (ABS 2010:42ff). 